\title{
Understanding the Influence of Visual Merchandising on Consumers' Impulse Buying Behaviour: Analysing the Literature
}

Azila Jaini, Wan Farha Wan Zulkiffli, Mohammad Ismail, Fatihah Mohd, Harniyati Hussin

To Link this Article: http://dx.doi.org/10.6007/IJARBSS/v12-i1/11277

DOI:10.6007/IJARBSS/v12-i1/11277

Received: 08 November 2021, Revised: 30 November 2021, Accepted: 25 December 2021

Published Online: 07 January 2022

In-Text Citation: (Jaini et al., 2022)

To Cite this Article: Jaini, A., Zulkiffli, W. F. W., Ismail, M., Mohd, F., \& Hussin, H. (2022). Understanding the Influence of Visual Merchandising on Consumers' Impulse Buying Behaviour: Analysing the Literature. International Journal of Academic Research in Business and Social Sciences, 12(1), 121-134.

Copyright: @ 2022 The Author(s)

Published by Human Resource Management Academic Research Society (www.hrmars.com)

This article is published under the Creative Commons Attribution (CC BY 4.0) license. Anyone may reproduce, distribute, translate and create derivative works of this article (for both commercial and non0-commercial purposes), subject to full attribution to the original publication and authors. The full terms of this license may be seen at: http://creativecommons.org/licences/by/4.0/legalcode

Vol. 12, No. 1, 2022, Pg. 121- 134

Full Terms \& Conditions of access and use can be found at http://hrmars.com/index.php/pages/detail/publication-ethics 


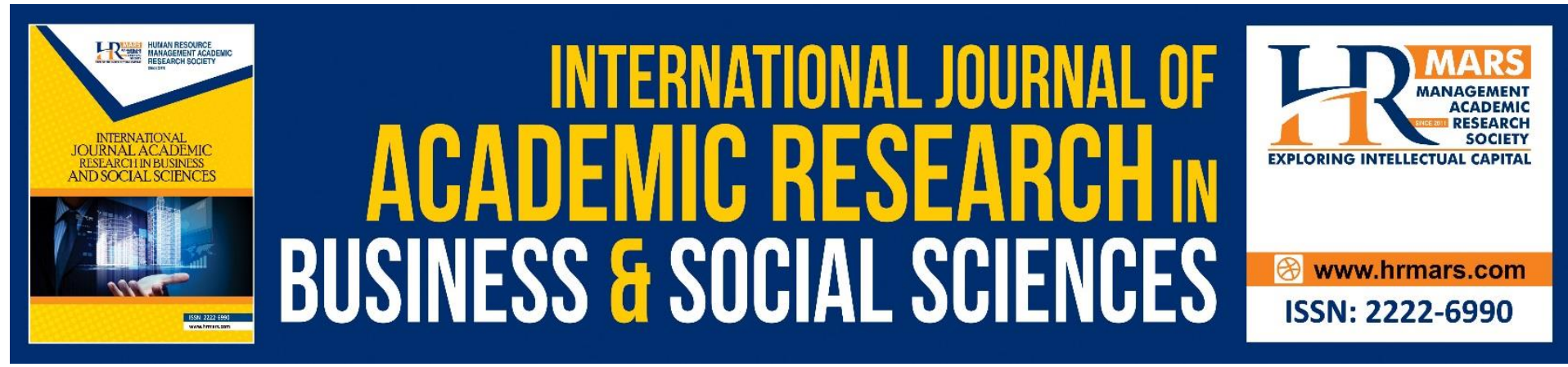

\title{
Understanding the Influence of Visual Merchandising on Consumers' Impulse Buying Behaviour: Analysing the Literature
}

\author{
Azila Jaini ${ }^{1}$, Wan Farha Wan Zulkiffli², Mohammad Ismail², \\ Fatihah Mohd ${ }^{2}$, Harniyati Hussin ${ }^{3}$ \\ ${ }^{1}$ Faculty of Business and Management, Universiti Teknologi MARA, Cawangan Johor Kampus \\ Segamat, Johor, Malaysia, ${ }^{2}$ Faculty of Entrepreneurship and Business, Universiti Malaysia \\ Kelantan, Pengkalan Chepa, Kelantan, Malaysia, ${ }^{3}$ Faculty of Business and Management, \\ Universiti Teknologi MARA, Cawangan Melaka, Melaka, Malaysia \\ Corresponding Author: azilajaini@uitm.edu.my
}

\begin{abstract}
The concept of visual merchandising is important to arouse internal emotions of customers to make impulse buying. This study is carried out to investigate important elements of visual merchandising that can stimulate customers' impulse buying behaviour. Based on thorough review on past literature, stimulus-organism-response (SOR) paradigm is utilized to develop conceptual framework in this study. Based on the review of past empirical findings, this study identified the elements of colour, lighting, mannequins, music and floor merchandising as important elements in attracting the customers' responses and results in impulse buying behaviour. The outcome of the study is expected to suggest a conceptual framework for future research to investigate customers' impulse buying behaviour in different retail stores from different regions. Furthermore, this study also provide an understanding for the retailers to emphasise on the specific elements of visual merchandising to increase the attention of customers to walk-in to their store and indirectly influence their purchase decision making. Keywords: Visual Merchandising, Impulse Buying Behaviour, Stimulus-Organism-Response
\end{abstract}

\section{Introduction}

The contagious pandemic Covid 19 has give tremendous effects to many industries including retail industry. The retail industry has been severely affected due to continuous Movement Order Control imposed by the Malaysian government. Due to intense competitive environments, all retailers started to strategize their effort in attracting more new buyers and retain them as long as possible (Gudonaviciene and Alijosiene, 2015). With the growth in consumer demand, lifestyle, and shopping behaviours, retail industry is facing tremendous changes due to globalisation and technology advancement that cause local retailers to face fierce competition in this industry. The impact of this pandemic not only affects the local retailers, however, big retailers such as Tesco and Giants also face huge losses. Furthermore, a new concept of shopping, which is, online shopping becomes a main preference by most 
consumers has created a barrier for local retailers to encourage people to visit their retail stores (Huang, 2016). Therefore, it is an urgent call for every local retailer to come out with effective strategies in order to enhance their retail performance and maintain their sustainability in the long run.

At the moment, Malaysia already open all borders across the states and all industries can operate based on specific Standard Operating Procedure (SOP) that has been outlined by the government. Therefore, taking this opportunity, the retailers can strategize an effective strategy through enhancing visual merchandising that can stimulate potential buyers' impulse buying and increase their tendency to walk into the store. This strategy is effective due to attractive sales environment through visual merchandising that can affect the potential buyers' emotions and indirectly influence their decision towards impulse buying (Gudonaviciene and Alijosiene, 2015). Furthermore, the attraction of visual merchandising on customers' impulse buying is able to increase the retailers' sales up to 62 percent (Mattila and Wirtz, 2008). In fact, retailers in the United States are able to achieve sales up to 80 percent from customers' impulse buying (Strack et al., 2006). Based on those reports, it is important to note that retailers need to enhance customers' feelings of excitement and interest to increase their impulse buying decision.

Prior research has found the behaviour of impulse buying is always associated with the strong desire and also the feeling of pleasure (Chan et al., 2017; Rook and Fisher, 1995). Additionally, customers frequently make unplanned purchase decisions especially when there are exposed to stimulating cues (Wu et al., 2020). It is believed that atmospheric environment such as colour, sense, taste, layout, and space are important cues that stimulate the attraction of customers to shop at the retail store (Oh et al., 2008). Furthermore, past studies suggested that store image is important in inspiring the customers' impulse buying behaviour, as to whether or not they visit a store, how much time they spend in it, and how much money they spend there (Oh et al., 2008; Zhu, 2009). Creative, professional merchandising of the display area is of vital importance and contributes significantly to the overall success of retailers. Both interior and exterior design of retail stores must be considered equally important in designing the store's image. Additionally, the tangible and intangible techniques are considered very important to stimulate customers' interest to visit a retail store (Bobiak, 2015; Lombart et al., 2018). Therefore, each element deserves an individual and in-depth investigation in order to help develop a more comprehensive understanding of customers' impulse buying behaviour in the retail market. Due to this reason, this study is carried out to gather important elements in visual merchandising that can influence customers' impulse buying behaviour in Malaysia. The findings of this study would be beneficial to the retailers to design their visual merchandising according to the interest of customers. Furthermore, the proposed conceptual framework gathered in this study can give more insight into the literature to study this issue from other perspectives.

To address the purpose of this study, a thorough literature review is conducted to gather important insight regarding impulse buying and visual merchandising elements needed in the retail store. Specific theory is discussed to understand the development of impulse buying behaviour among customers. Then, detailed justification on each element of visual merchandising is highlighted and discussion and conclusion is derived in this study. Finally, limitations and recommendations for future research are presented at the end of this study.

\section{Theoretical Framework}

Stimulus-Organism-Response (SOR) Model 
Stimulus-organism-response model was developed by Mehrabian and Russell (1974). This model explains consumer behaviour was directed by stimulus factors that enhance the internal state of people (organism) and then this emotion later transforms into specific behaviour (Mehrabian and Russell, 1974). Stimulus is defined as any factors that influence or stimulate the internal emotion of an individual (Eroglu et al., 2001). In consumer behaviour studies, stimulus can be considered as external factors that consist of marketing mix or environmental inputs (Bagozzi, 1986). In the context of shopping at retail stores, the stimulus is the elements in visual merchandising displayed by the retailers.

The organism is the outcome of the stimulus factors. It refers to the internal processes and structures that interfere between external stimuli and the final outcomes, feedbacks, or responses derived by the individual (Mehrabian and Russell, 1974). These interference processes and structures are involved with an individual's feelings, physiological and cognitive influence (Bagozzi, 1986). Based on the SOR model, organism consists of pleasure, arousal, and dominance (PAD), which represent affective or emotional, and cognitive processes that mediate the relationship between stimulus and individuals' behavioural responses (Mehrabian and Russell, 1974). In this study context, organism is classified as a positive emotional response displayed by customers when they are exposed to specific cues that consist of the elements of visual merchandising.

Next, a response is the outcome of the SOR model. It can be considered as the outcome or final decision made by customers. In explaining behaviour of customers, response can be classified as favourable or unfavourable actions present by consumers based on the positive or negative organism received by them (Donovan and Rossiter 1982; Sherman et al., 1997). Therefore, this study classified customers' response in terms of impulse buying behaviour where they make an unplanned purchase based on the stimulus (visual merchandising) present in the retail store that direct their positive emotional response to conduct purchase activities immediately.

Past research numerously adapted the SOR model in explaining impulse buying behaviour in various research contexts such as media multitasking (Chang, 2017), shopping in specialised clothing and footwear stores (Gudonaviciene and Alijosiene, 2015), buying through social commerce (Huang, 2016) and mobile commerce (Zheng et al., 2019). By following these notions, this study adapted the SOR model in explaining the influence of visual merchandising elements on customers' positive responses that results in their impulse buying behaviour. Figure 1 below presents the stimulus-organism-response framework by Mehrabian and Russell (1974).

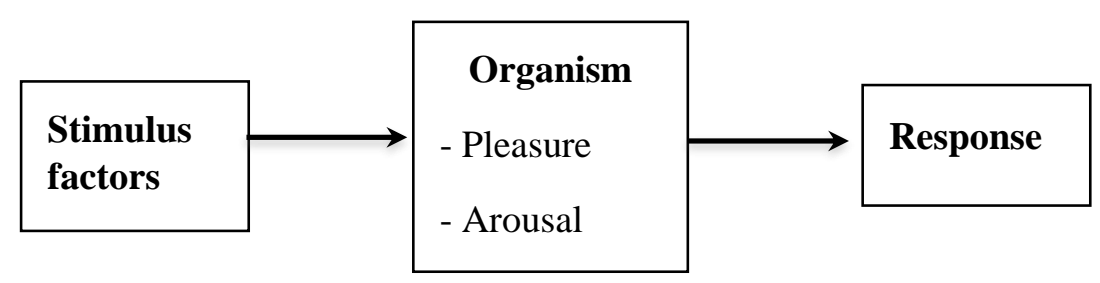

Figure 1: Stimulus-Organism-Response Model

Impulse Buying Behaviour

Stern (1962) defined impulse buying as a purchase decision made by the shopper without a proper plan in advance. Meanwhile, Rook (1987) defined impulse buying as a unique, extraordinary, and exciting purchase experience that is directed by immediate and strong 
feelings that urgently influence their decision to purchase. Then, a study conducted by Rook and Fisher (1995) described impulse buying as an immediate, spontaneous, and unreflectively purchase made by customers. Based on the SOR model, customers' buying attitude is influenced by the stimulus received upon their experience in that situation where it's indirectly affecting their emotional states (organism), which result in their behaviour (response) (Mehrabian and Russell, 1974). Therefore, from the context of shopping experience, impulse buying can be considered as customers' purchase decisions that involve no specific intention to buy at the first time and are stimulated due to specific cues displayed by the retail stores.

From the perspective of retail industry, creating effective visual merchandising is able to stimulate customers' impulse buying behaviour (Gudonaviciene and Alijosiene, 2015). It is because the impulse to buy is hedonically complex and may stimulate emotional conflict. Therefore, it is important for retailers to provide an attractive visual merchandising display that can enhance customers' positive feelings towards the retail stores. For example, fashion retailers are often used visual merchandising display as an attractive tool to visually communicate customers' impulse buying by arousing their positive emotions (Sundstrom et al., 2019). Therefore, the elements of visual merchandising act as cues that trigger customers' positive responses to behave impulsively. The trigger factors are divided into two types such as external cues and internal cues. External cues are specific triggers associated with buying or shopping. They involve marketer-controlled environmental and sensory factors. Meanwhile, internal cues refer to customers' self-feelings, moods, and emotional states (Wansink 1994). Recent studies have stated that atmospheric cues in the retail environment are important triggers that can influence a desire to purchase impulsively (Eroglu and Machleit 1993; Mitchell 1994). As stated by Zolkifly and Baharom (2016), visual merchandising is able to act as external cues that engage with the senses of customers where more engagement with these senses creates a stronger response for consumers to make more purchases.

Prior research also found that impulse buying is a successful strategy in increasing the sales volume of retail stores (Mattila and Wirtz, 2008; Strack et al., 2006). Due to this situation, many retailers put a lot of effort into coordinating proper visual merchandising (stimulus) to enhance customers' happiness and excitement (organism) in their shopping experience and indirectly stimulate their impulse buying behaviour (responses) (Chang et al., 2011). Considering this, proper understanding of visual merchandising elements is an urgent call to encourage more impulse buying decisions from customers. The elements of visual merchandising are further discussed in the section.

\section{Elements of Visual Merchandising}

Visual merchandising can be defined as any interior and exterior design created to be seen by the customers for the purpose to create a good business' image, which results in positive customers' attention, interest, appeal and action (Bastow-Shoop et al., 1991). Meanwhile, Kerfoot et al. (2003) defined visual merchandising as visual communication of products or brands to customers for the purpose to acknowledge customers and creating a positive response, which results in the purchase of a product. A good arrangement of visual merchandising is able to enhance the attractiveness of a store. Additionally, an effective visual merchandising arrangement is useful in encouraging customers' impulse buying behaviour. The elements of visual merchandising such as window display consist of lighting, colour, material, and art compositions (mannequins, graphics), props, product display, store layout, 
in-store design, and promotional signage. Other elements of visual merchandising include music, floor merchandising, utilitarian aspects, sign, logos, marquees, banners, landscapes, store fixtures, and other decorations.

Prior study has found a positive impact of mannequin display and promotional signage on customers' impulse buying behaviour among Indian respondents (Bashar and Irshad, 2012). Based on statistical results by using SPPS software, the findings show that window display and floor merchandising are positively correlated with impulsive purchase meanwhile store display is not correlated. Furthermore, another study conducted at the supermarkets in Sri Lanka has found that product display was the most important element of visual merchandising in influencing the patronage of customers to purchase a product (Gajayanake and Surangi, 2011). Besides product display, other significant elements that attract customers' patronage intention are colour environment display in the supermarket, music background, lighting, and cleanliness. Nevertheless, store layout was not a significant element towards customers' patronage intention.

Besides that, a study on visual merchandising also has been conducted in a different country such as Lithuania and found that window display and in-store design are the most influential factors towards customers' impulse buying in the context of clothing and footwear purchases (Gudonaviciene and Alijosiene, 2015). The empirical findings support the attractiveness of stylish and original window display and in-store design that are able to stimulate consumers' responses and direct their actions towards impulse buying decisions.

Furthermore, another study was conducted in Sweden has found that in-store product display and product shelf presentation are the most influential factors on consumers' impulse buying behaviour among Swedish as compared to store layout and promotional signage (Hubrechts and Kokturk, 2012). Here, it showed that the arrangement of products and gondolas in grocery stores play an important role in attracting customers' immediate response to purchase a product. Another research conducted in the restaurants in Slovakia has found that lighting, music, and colour background play a major influence in attracting the customers to dine in at the chosen restaurants (Kleinova et al., 2015). All these three elements are able to affect the taste of the meals where it indirectly arouses the emotions of consumers to deliver positive feelings on the meals they consumed.

In the context of apparel shopping experience, a prior study indicated that two main aspects of evaluation that consist of utilitarian and hedonic aspects that give diverse impact on customers' affective response in Hong Kong (Law et al., 2012). Hedonic aspect is focused on the emotional response of customers meanwhile the utilitarian aspect is subject to the product's functions. Therefore, the elements of visual merchandising that represent hedonic value are mannequins, colour, lighting, and props and the example of utilitarian aspects consist of garment deterioration, seasonal changes, and occasions. The findings of the study revealed that both aspects are important in stimulating customers' response to shop apparel products (Law et al., 2012).

Additionally, Sujata et al (2012) have found important visual merchandising elements as the antecedent to impulse buying among Indian customers. The study had chosen window display, form display, floor merchandising, and promotional signage as independent variables. The sample of the study consists of both male and female customers ranging from 18-45 years old and the results were analysed by using Pearson correlation. Then, the findings derived from the study showed that there is a strong correlation between window display and form display towards impulse buying. However, low correlation is found between impulse buying and floor merchandising. 
In the context of car selling in Malaysia showrooms, a prior study has suggested several elements of visual merchandising that can be used in the showroom to make it more interesting to stimulate customers' buying response (Zolkifly and Baharom, 2016). The elements that have been highlighted in the study are storefront, store layout, store interior, and interior display. Storefront refers to the exterior layout that includes a store's sign or logo, marquee, outdoor lighting, banners, planters, awnings, windows, exterior design, ambiance, landscaping, and lighting of the building. Meanwhile, store layout is the floor space designed to facilitate and promote sales and serve customers and store interior consists of materials or tools used inside the store such as mannequins, seating, props, floor and wall coverings, lighting, colour, store fixtures, interior signage, and graphics. Additionally, interior display consist of closed, open, architectural, point of purchase displays and store decorations. Table 1 summarized past literature research and findings pertaining to visual merchandising influence on consumers' response and impulse buying behaviour.

Table 1: Summary of Past Literature on Visual Merchandising

\begin{tabular}{|c|c|c|c|c|}
\hline Authors & Title & $\begin{array}{l}\text { Research } \\
\text { Objectives }\end{array}$ & $\begin{array}{l}\text { Country } \\
\text { Context }\end{array}$ & Generated Factors \\
\hline $\begin{array}{l}\text { Bashar and } \\
\text { Irshad (2012) }\end{array}$ & $\begin{array}{l}\text { Visual } \\
\text { merchandising } \\
\text { and consumer } \\
\text { impulse buying } \\
\text { behaviour: An } \\
\text { empirical study } \\
\text { of Delhi and } \\
\text { NCR. }\end{array}$ & $\begin{array}{l}\text { To examine the } \\
\text { relationship } \\
\text { between } \\
\text { consumer impulse } \\
\text { buying behaviours } \\
\text { and visual } \\
\text { merchandising. }\end{array}$ & India & $\begin{array}{l}\text { 1. Mannequin } \\
\text { display } \\
\text { 2. Promotional } \\
\text { signage }\end{array}$ \\
\hline $\begin{array}{l}\text { Gajayanake } \\
\text { and Surangi } \\
\text { (2011) }\end{array}$ & $\begin{array}{l}\text { The impact of } \\
\text { selected visual } \\
\text { merchandising } \\
\text { techniques on } \\
\text { patronage } \\
\text { intentions in } \\
\text { supermarkets } \\
\text { (study based } \\
\text { on Colombo } \\
\text { district) }\end{array}$ & $\begin{array}{l}\text { - To identify the } \\
\text { most important } \\
\text { visual } \\
\text { merchandising } \\
\text { techniques that } \\
\text { would influence } \\
\text { patronage } \\
\text { intentions in } \\
\text { supermarkets } \\
\text { within the } \\
\text { Colombo city } \\
\text { limits. } \\
\text { - To identify the } \\
\text { widely used visual } \\
\text { merchandizing } \\
\text { techniques by } \\
\text { different } \\
\text { supermarket } \\
\text { chains in } \\
\text { operating in the } \\
\text { Colombo city } \\
\text { limits. }\end{array}$ & Sri Lanka & $\begin{array}{l}\text { 1. Colour } \\
\text { 2. Product display } \\
\text { 3. Music } \\
\text { 4. Lighting } \\
\text { 5. Cleanliness }\end{array}$ \\
\hline
\end{tabular}




\begin{tabular}{|c|c|c|c|c|}
\hline $\begin{array}{l}\text { Gudonaviciene } \\
\text { and Alijosiene } \\
\text { (2015) }\end{array}$ & $\begin{array}{l}\text { Visual } \\
\text { merchandising } \\
\text { impact on } \\
\text { impulse buying } \\
\text { behaviour }\end{array}$ & $\begin{array}{l}\text { To reveal what } \\
\text { visual } \\
\text { merchandising } \\
\text { elements make } \\
\text { the highest } \\
\text { positive impact on } \\
\text { impulse buying for } \\
\text { consumers in } \\
\text { Lithuania when } \\
\text { shopping in } \\
\text { specialised } \\
\text { clothing and } \\
\text { footwear stores }\end{array}$ & Lithuania & $\begin{array}{l}\text { 1. Windows display } \\
\text { 2. Store layout } \\
\text { 3. In-store design } \\
\text { 4. Promotional } \\
\text { signage } \\
\text { 5. Store atmosphere } \\
\text { (lighting, colours) }\end{array}$ \\
\hline $\begin{array}{l}\text { Hubrechts and } \\
\text { Kokturk (2012) }\end{array}$ & $\begin{array}{l}\text { Effects of visual } \\
\text { merchandising } \\
\text { on young } \\
\text { consumers' } \\
\text { impulse buying } \\
\text { behaviour }\end{array}$ & $\begin{array}{l}\text { To study the } \\
\text { effectiveness of } \\
\text { visual } \\
\text { merchandising on } \\
\text { impulse buying } \\
\text { behaviour. }\end{array}$ & Sweden & $\begin{array}{l}\text { 1. In-store product } \\
\text { display } \\
\text { (merchandise } \\
\text { display, } \\
\text { architectural/artistic } \\
\text { display, point-of- } \\
\text { sale display) } \\
\text { 3. Product } \\
\text { presentation } \\
\text { (product placement, } \\
\text { gondola) }\end{array}$ \\
\hline $\begin{array}{l}\text { Kleinova et al. } \\
\text { (2015) }\end{array}$ & $\begin{array}{l}\text { Visual } \\
\text { merchandising } \\
\text { and its } \\
\text { marketing } \\
\text { components in } \\
\text { the chosen } \\
\text { restaurants in } \\
\text { Slovakia }\end{array}$ & $\begin{array}{l}\text { To evaluate what } \\
\text { kind of visual } \\
\text { merchandising's } \\
\text { components the } \\
\text { restaurants use in } \\
\text { their businesses. }\end{array}$ & Slovakia & $\begin{array}{l}\text { 1. Lighting } \\
\text { 2. Musical } \\
\text { background } \\
\text { 7. Background } \\
\text { colour }\end{array}$ \\
\hline $\begin{array}{l}\text { Law et al. } \\
\text { (2012) }\end{array}$ & $\begin{array}{l}\text { How does } \\
\text { visual } \\
\text { merchandising } \\
\text { affect } \\
\text { consumer } \\
\text { affective } \\
\text { response? An } \\
\text { intimate } \\
\text { apparel } \\
\text { experience }\end{array}$ & $\begin{array}{l}\text { To investigate the } \\
\text { relationship } \\
\text { between visual } \\
\text { merchandising } \\
\text { elements and } \\
\text { consumer } \\
\text { affective response } \\
\text { by focusing on a } \\
\text { function-oriented } \\
\text { product-intimate } \\
\text { apparel. }\end{array}$ & $\begin{array}{l}\text { Hong } \\
\text { Kong }\end{array}$ & $\begin{array}{l}\text { 1. Utilitarian aspects } \\
\text { - garment } \\
\text { deterioration } \\
\text { - seasonal changes } \\
\text { - occasions } \\
\text { 2. Hedonic aspects } \\
\text { - windows display } \\
\text { (mannequins, } \\
\text { colour, lighting, } \\
\text { props) }\end{array}$ \\
\hline $\begin{array}{l}\text { Sujata et al. } \\
(2012)\end{array}$ & $\begin{array}{l}\text { Visual } \\
\text { merchandising } \\
\text { as an } \\
\text { antecedent to }\end{array}$ & $\begin{array}{l}\text { To examine the } \\
\text { relationship } \\
\text { between } \\
\text { respondents' }\end{array}$ & India & $\begin{array}{l}\text { 1. Window display } \\
\text { 2. Form display } \\
\text { (mannequin) }\end{array}$ \\
\hline
\end{tabular}




\begin{tabular}{|l|l|l|l|l|}
\hline & $\begin{array}{l}\text { impulse buying: } \\
\text { An Indian } \\
\text { perspective }\end{array}$ & $\begin{array}{l}\text { impulse buying } \\
\text { behaviour and } \\
\text { common external } \\
\text { factors that } \\
\text { trigger impulse } \\
\text { buying. }\end{array}$ & & \\
& $\begin{array}{l}\text { Zolkifly and } \\
\text { Baharom } \\
(2016)\end{array}$ & $\begin{array}{l}\text { Selling Cars } \\
\text { through Visual } \\
\text { Merchandising: } \\
\text { Proposing } \\
\text { Emotional } \\
\text { Design } \\
\text { Approach }\end{array}$ & $\begin{array}{l}\text { To identify the } \\
\text { roles of visual } \\
\text { merchandising } \\
\text { inside a car } \\
\text { showroom as } \\
\text { stimuli that } \\
\text { attract customers } \\
\text { at the point of } \\
\text { sale i.e. the car } \\
\text { dealership and } \\
\text { proposing } \\
\text { emotional design } \\
\text { approach in } \\
\text { designing car } \\
\text { showroom. }\end{array}$ & Malaysia \\
& & & $\begin{array}{l}\text { 1. Storefront (sign, } \\
\text { logo, marquee, } \\
\text { banners, } \\
\text { landscaping, lighting } \\
\text { of the building, } \\
\text { outdoor lighting). } \\
\text { 2. Store layout } \\
\text { (floor space) } \\
\text { 3. Store interior } \\
\text { (mannequins, } \\
\text { props, lighting, } \\
\text { colour, store } \\
\text { fixtures, interior } \\
\text { signage and } \\
\text { graphics). } \\
\text { 4. Interior display } \\
\text { (decorations, point } \\
\text { of purchase display- } \\
\text { windows display) }\end{array}$ \\
\hline
\end{tabular}

Based on empirical findings from past literature, Table 2 and Table 3 list all the elements that give positive impact on customers' responses and their impulse buying behaviour. From this table, several important elements can be identified and used in the development of conceptual framework in the present study. 
INTERNATIONAL JOURNAL OF ACADEMIC RESEARCH IN BUSINESS AND SOCIAL SCIENCES

Vol. 12, No. 1, 2022, E-ISSN: 2222-6990 @ 2022 HRMARS

Table 2: Elements of Windows Display

\begin{tabular}{|c|c|c|c|c|c|c|c|c|c|c|}
\hline Authors & $\begin{array}{l}\text { Colo } \\
\text { ur }\end{array}$ & $\begin{array}{l}\text { Lighti } \\
\text { ng }\end{array}$ & $\begin{array}{l}\text { Pro } \\
\text { ps }\end{array}$ & $\begin{array}{l}\text { Mann } \\
\text { equin }\end{array}$ & $\begin{array}{l}\text { Grap } \\
\text { hic }\end{array}$ & $\begin{array}{l}\text { Pro } \\
\text { duct } \\
\text { disp } \\
\text { lay }\end{array}$ & $\begin{array}{l}\text { Point-of- } \\
\text { purchase } \\
\text { display }\end{array}$ & $\begin{array}{l}\text { Stor } \\
\text { e } \\
\text { layo } \\
\text { ut }\end{array}$ & $\begin{array}{l}\text { In- } \\
\text { store } \\
\text { design }\end{array}$ & $\begin{array}{l}\text { Promoti } \\
\text { onal } \\
\text { signage }\end{array}$ \\
\hline $\begin{array}{l}\text { Bashar and } \\
\text { Irshad (2012) }\end{array}$ & & & & $\checkmark$ & & & & & & $\checkmark$ \\
\hline $\begin{array}{l}\text { Gajayanake } \\
\text { and Surangi } \\
(2011)\end{array}$ & $\checkmark$ & $\checkmark$ & & & & $\checkmark$ & & & & \\
\hline $\begin{array}{l}\text { Gudonavicien } \\
\text { e and } \\
\text { Alijosiene } \\
\text { (2015) }\end{array}$ & $\checkmark$ & $\checkmark$ & & & & & & $\checkmark$ & $\checkmark$ & $\checkmark$ \\
\hline $\begin{array}{l}\text { Hubrechts } \\
\text { and Kokturk } \\
(2012)\end{array}$ & & & & & & $\checkmark$ & & & & \\
\hline $\begin{array}{l}\text { Kleinova et al. } \\
(2015)\end{array}$ & $\checkmark$ & $\checkmark$ & & & & & & & & \\
\hline $\begin{array}{l}\text { Law et al. } \\
(2012)\end{array}$ & $\checkmark$ & $\checkmark$ & $\checkmark$ & $\checkmark$ & & & & & & \\
\hline $\begin{array}{l}\text { Sujata et al. } \\
(2012)\end{array}$ & & & & $\checkmark$ & & & & & & $\checkmark$ \\
\hline $\begin{array}{l}\text { Zolkifly and } \\
\text { Baharom } \\
\text { (2016) }\end{array}$ & $\checkmark$ & $\checkmark$ & $\checkmark$ & $\checkmark$ & $\checkmark$ & & $\checkmark$ & & & \\
\hline
\end{tabular}

Table 3: Other Elements of Visual Merchandising

\begin{tabular}{|l|l|l|l|l|l|l|l|l|l|l|}
\hline Authors & $\begin{array}{l}\text { Utilitari } \\
\text { an } \\
\text { aspects }\end{array}$ & $\begin{array}{l}\text { Musi } \\
\text { c }\end{array}$ & $\begin{array}{l}\text { Floor } \\
\text { Merchan } \\
\text { dising }\end{array}$ & $\begin{array}{c}\text { Sig } \\
\text { n, } \\
\text { log } \\
\text { o }\end{array}$ & $\begin{array}{l}\text { Marq } \\
\text { uee }\end{array}$ & $\begin{array}{c}\text { Banne } \\
\text { rs }\end{array}$ & $\begin{array}{l}\text { Landsc } \\
\text { ape }\end{array}$ & $\begin{array}{l}\text { Stor } \\
\text { e } \\
\text { fixtu } \\
\text { res }\end{array}$ & $\begin{array}{l}\text { Decorati } \\
\text { ons }\end{array}$ & $\begin{array}{l}\text { Cleanlin } \\
\text { ess }\end{array}$ \\
\hline $\begin{array}{l}\text { Bashar and } \\
\text { Irshad (2012) }\end{array}$ & & $\checkmark$ & & & & & & & \\
\hline $\begin{array}{l}\text { Gajayanake } \\
\text { and Surangi } \\
\text { (2011) }\end{array}$ & & $\checkmark$ & & & & & & & & $\checkmark$ \\
\hline $\begin{array}{l}\text { Kleinova et } \\
\text { al. (2015) }\end{array}$ & $\checkmark$ & $\checkmark$ & & & & & & & & \\
\hline $\begin{array}{l}\text { Law et al. } \\
\text { (2012) }\end{array}$ & $\checkmark$ & & & & & & & & & \\
\hline $\begin{array}{l}\text { Sujata et al. } \\
\text { (2012) }\end{array}$ & & & $\checkmark$ & & & & & & & \\
\hline $\begin{array}{l}\text { Zolkifly and } \\
\text { Baharom } \\
\text { (2016) }\end{array}$ & & $\checkmark$ & $\checkmark$ & $\checkmark$ & $\checkmark$ & $\checkmark$ & $\checkmark$ & $\checkmark$ & $\checkmark$ & \\
\hline
\end{tabular}


According to Table 2 and Table 3, three elements of window display such as colour, lighting, and mannequin were identified as the most influential factors based on the findings in the past studies. Meanwhile, music and floor merchandising are other important elements of visual merchandising that positively reflect consumers' responses. Therefore, this study considered these five factors as elements in visual merchandising that can influence consumers' impulse buying behaviour.

\section{Propose Conceptual Framework}

As discussed in the previous section, this study identified three important elements of visual merchandising that give a stronger impact on consumers' emotion and then results in their impulse buying decision. Based on the stimulus-organism-response model, this study conceptualized a proposed research framework adapted from the SOR model. Figure 2 below presents the proposed conceptual framework derived from this study.

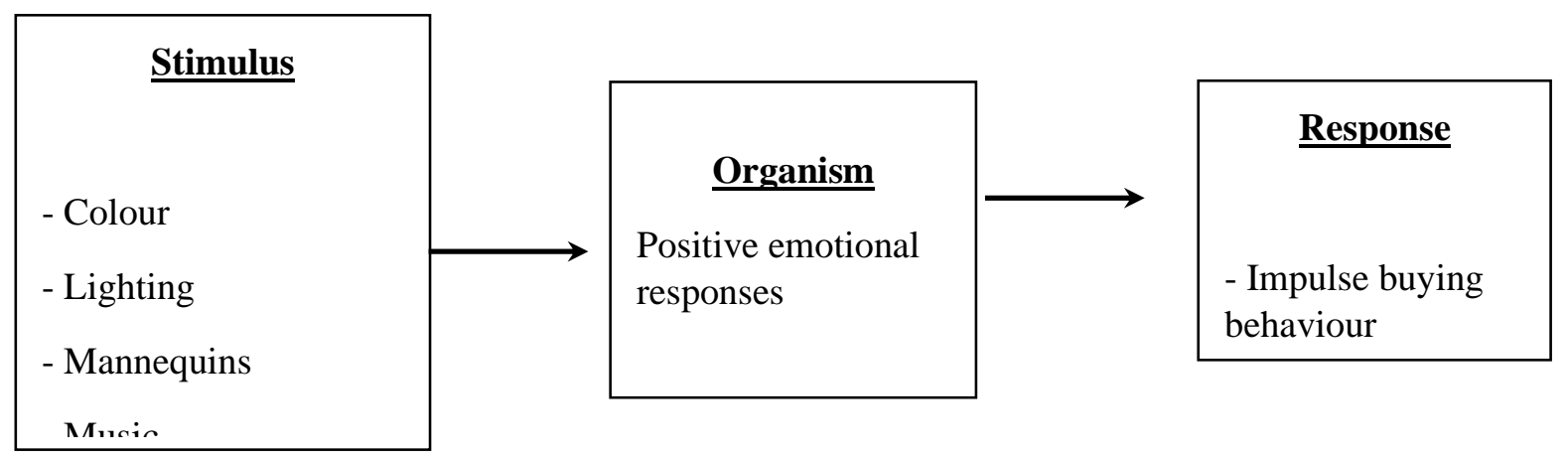

Figure 2: Proposed Conceptual Framework

\section{Discussions and Conclusion}

The aim of this study is to identify the elements of visual merchandising that can influence customers' impulse buying based on the review from past studies' findings in various research contexts. Based on the adaptation of stimulus-response-organism paradigm, this study developed a proposed conceptual framework that explains the relationship of cues (elements of visual merchandising), customers' positive responses, and impulse buying behaviour. Based on the conceptual framework, this study comes out with three major elements of visual merchandising that have mostly been discussed as significant factors in the past literature that consists of windows display, colour, and lighting in the retail stores.

Window display represents an important medium of communication with customers. It can attract the eyes of customers from various designs. For example, most of past findings indicated colour, lighting, and mannequins as the influential factors that can attract customers' response (Gajayanake and Surangi, 2011; Gudonaviciene and Alijosiene, 2015; Kleinova et al., 2015; Law et al., 2012); Sujata et al., 2012; Zolkifly and Baharom, 2016). Therefore, it showed that the concepts of window display could expand the perspectives of customers and convey useful messages that can convince the customers' purchase decision making. Additionally, it is believed that an effective window display design will give a favourable impact on viewers, to convey designated merchandising strategic messages effectively to a product's target group, to optimally respond to a mission of products, and hopefully to provide further impetus for visual merchandizing development (Kernsom and Sahachaisaeree, 2012).

Apart from window display, music, and floor merchandising are also crucial in stimulating 
customers' positive responses that can increase their tendency in making impulse buying (Bashar and Irshad, 2012; Gajayanake and Surangi, 2011; Kleinova et al., 2015; Zolkifly and Baharom, 2016). Here, it showed that music could give stronger effects on perceptions and preferences of customers where it can retain the customers much longer in the stores (Gajayanake and Surangi, 2011). Furthermore, floor merchandising is expected can facilitate and promote sales to customers effectively (Zolkifly and Baharom, 2016).

In the nutshell, based on the previous findings, this study considered background of colour, lighting, mannequins, music, and floor merchandising as important elements that must be considered by the retailers in influencing their customers' impulse buying behaviour. Perhaps this study is helpful for future studies to adapt the proposed conceptual framework and empirically investigate the customers' impulse buying behaviour from different research contexts. Furthermore, the results of the study are useful for the retailers, marketers, and designers to modify their store image and adapt suggested elements of visual merchandising in their stores.

\section{References}

Bagozzi, R. P. (1986). Principles of marketing management. Chicago: Science Research Associates.

Bashar, A., and Irshad, A. (2012). Visual merchandising and consumer impulse buying behavior: An empirical study of Delhi \& NCR. International Journal of Retail Management \& Research, 2.

Bastow-Shoop, H., Zetocha, D., \& Passewitz, G. (1991). Visual merchandising: A guide for small retailers. lowa: University Publications.

Bobiak, M. (2015). The science of retail visual merchandising and consumer behavior. Retrieved from http://bigeyeagency.com/the-invaluable-retail-visual-merchandisingagency-partnership/?nabt=0

Chan, T. K., Cheung, C. M., \& Lee, Z. W. (2017). The state of online impulse-buying research: A literature analysis. Information and Management, 54(2), 204-217.

Chang, Y. (2017). The influence of media multitasking on the impulse to buy: A moderated mediation model. Computers in Human Behavior, 70, 60-66.

Chang, H.-J., Eckman, M., \& Yan, R.-N. (2011). Application of the Stimulus-Organism-Response model to the retail environment: the role of hedonic motivation in impulse buying behavior. The International Review of Retail, Distribution and Consumer Research, 21(3), 233-249.

Eroglu, S. A., \& Machleit, K. A. (1993). Atmospheric factors in the retail environment: Sights, sounds and smells. Advances in Consumer Research, 20, 34.

Gajayanake, R., \& Surangi, H. A. K. N. S. (2011). The impact of selected visual merchandising techniques on patronage intentions in supermarkets (study based on Colombo district). 2nd International Conference on Business and Economic Research (2nd ICBER 2011). Proceeding.

Gudonaviciene, R., \& Alijosiene, S. (2015). Visual merchandising impact on impulse buying behaviour, Social and Behavioral Sciences, 213, 635-640.

Hubrechts, L., \& Kokturk, B. (2012). Effects of visual merchandising on young consumers' impulse buying behaviour. Marketing Report. Sweden: Halmstad University Reproservice.

Huang, Li-T. (2016). Flow and social capital theory in online impulse buying. Journal of Business Research, 69, 2277-2283. 
Kernsom, T., \& Sahachaisaeree, N. (2012). Strategic merchandising and effective composition design of window display: A case of large scale department store in Bangkok. ProcediaSocial and Behavioral Sciences, 42, 422-428.

Kerfoot, S., Davies, B., \& Wards, B. (2003). Visual merchandising and the creation of discernible retail brands. International Journal of Retail \& Distribution Management, 31 (3), 143-152.

Kleinova, K., Paluchova, J., Bercik, J., \& Horska, E. (2015). Visual merchandising and its marketing components in the chosen restaurants in Slovakia. Procedia Economics and Finance, 34, 3-10.

Law, D., Wong, C., \& Yip, J. (2012). How does visual merchandising affect consumer affective response? An intimate apparel experience. European Journal of Marketing, 46(1/2), 112-133.

Lombart, C., Labbe-Pinlon, B., Filser, M., Anteblian, B., \& Louis D. (2018). Regional product assortment and merchandising in grocery stores: Strategies and target customer segments. Journal of Retailing and Consumer Services, 42, 117-132.

Mattila, A. S., \& Wirtz, J. (2008). The role of store environmental stimulation and social factors on impulse purchasing. Journal of Services Marketing, 22, 562-567.

Mehrabian, A., \& Russell, J. A. (1974). An approach to environmental psychology. Cambridge, MA: The MIT Press.

Mitchell, D. J. (1994). For the smell of it all: Functions and effects of olfaction in consumer behavior. Advances in Consumer Research, 21, 330.

Oh, J., Fiorito, S. S., Cho, H., \& Hofacker, C. F. (2008). Effects of design factors on store image and expectation of merchandise quality in web-based stores. Journal of Retailing and Consumer Services, 15, 237-249.

Rook, D. W., \& Fisher, R. J. (1995). Normative influences on impulsive buying behavior. Journal of Consumer Research, 22(3), 305-313.

Stern, H. (1962). The significance of impulse buying today. Journal of Marketing, 26(2), 5962.

Strack, F., Werth, L., \& Deutsch, R. (2006). Reflective and impulsive determinants of consumer behavior. Journal of Consumer Psychology, 16 (3), 205-216.

Sujata, K., Bhawna, A., \& Anju, G. (2012). Visual merchandising as an antecedent to impulse buying: An Indian perspective. International Journal of Business and Management Studies, 1(1), 267-277.

Sundstrom, M., Hjelm-Lidholm, S., \& Radon, A. (2019). Clicking the boredom away: Exploring impulse fashion buying behavior online. Journal of Retailing and Consumer Services, 47, 150-156.

Wansink, B. (1994). The dark side of consumer behavior: Empirical examinations of impulsive and compulsive consumption. Advances in Consumer Research, 21, 508.

Wu, I.-L., Chiu, M.-L., \& Chen, K.-W. (2020). Defining the determinants of online impulse buying through a shopping process of integrating perceived risk, expectationconfirmation model, and flow theory issues. International Journal of Information Management, 52, 1-12.

Zheng, X., Men, J., Yang, F., \& Gong, X. (2019). Understanding impulse buying in mobile commerce: An investigation into hedonic and utilitarian browsing. International Journal of Information Management, 48, 151-160.

Zhu, L. (2009). Effective visual merchandising in fashion retailing (Doctoral thesis, University of Leeds, United Kingdom. Retrieved from http://etheses.whiterose.ac.uk/11290/ 
INTERNATIONAL JOURNAL OF ACADEMIC RESEARCH IN BUSINESS AND SOCIAL SCIENCES

Vol. 11, No. 12, 2021, E-ISSN: 2222-6990 @ 2021 HRMARS

Zolkifly, N. H., \& Baharom, S. N. (2016). Selling cars through visual merchandising: Proposing emotional design approach. Procedia Economics and Finance, 37, 412-417. 